required for Microbiologists recruited to the Food Industry". The scope for microbiologists in this field has increased considerably in the past ten years, but it is not true to say that there is a large unsatisfied demand for microbiologists. Newly engaged staff lack the necessary specialized knowledge and require a good deal of training. Courses in microbiology should contain more of the processing, preservation and spoilage of foods. Yeasts and moulds are of considerable importance in the industry and should be studied as well as bacteria. Mr. H. Proom, who spoke on "Training required for Technicians in Microbiological Laboratories", said that there is at present a grave need for microbiological technicians. To improve the supply it seems necessary that (1) the work and responsibilities be defined, (2) qualifications must receive general recognition and be correlated with wage scales, and (3) there must be a sufficiently large total number of posts. Industry must give the lead with respect to (1), but work and responsibilities are difficult to define because of the variety of conditions and opportunities. Some of the technician's work is bound to be routine, and no ambitious scheme of training is necessary. Training at this level in industry itself is wasteful, and courses in technical colleges, such as that included in the City and Guilds scheme, seem satisfactory. Training in highly specialized work, electron micrography, for example, is more appropriately given in the course of employment.

From the discussion which followed these papers, it seemed that there was fairly general agreement that the primary object of degree courses in microbiology should be to give a broad training in fundamentals. Of course, indications of practical applications should be given, but it is not for the universities to train for specific industrial outlets. Chemistry is undoubtedly a basic subject for the microbiologist, but the idea that the chemist is just as well able to deal with microbiological processes as the microbiologist was repudiated by many speakers. The biological outlook is essential in industrial microbiology, although it is perhaps true to say that the microbiologist is a specialist whose work is utilized most efficiently if he is supported by a team of chemists. Discussion of the suitability of microbiology as a subject for a first degree was inconclusive. Attention was directed to the fact that microbiology now forms a substantial part of degree courses in pharmacy. For the training of microbiological technicians it was agreed that the City and Guilds scheme meets the need for an elementary non-medical training course. There is clearly room for expansion of courses at this level and there remains a lack of general courses of a more advanced kind for technicians which will perhaps be supplied by those for the advanced level endorsed certificate of the Institute of Biology. Classes cannot be started until a demand exists, but employers are unwilling to send technicians to courses which have not been established. The initiative in breaking this vicious circle must surely come from industry.

G. E. Foge

\title{
OBITUARIES
}

\section{Sir Arthur Bowley, C.B.E., F.B.A.}

Arthor Lyon Bowlex died on January 21 at the age of eighty-seven. He was the last of the distinguished statisticians and economists practising at the end of the nineteenth century, and the last of the original group of teachers at the London School of Economics. $\mathrm{He}$ will be long remembered, both for his teaching during an active life of fifty years and for his many writings on statistics and on economic and social affairs.

At Trinity College, Cambridge, he was bracketed tenth Wrangler in 1891 and stayed on to gain the Cobden Prize in 1892 with his "A Short Account of England's Foreign Trade in the Nineteenth Century" (published 1893, third edition 1922). Later he obtained the Adam Smith Prize (1894) and the Sc.D. (1913); he was also awarded honorary doctorates by Oxford and Manchester.

For nearly twenty-five years from 1895, Bowley was a part-time teacher of mathematics and statistics at the London School of Economics in the University of London, during a period when statistics was not taught as a separate subject at any other university. He combined this with additional teaching, first as a mathematics master at St. John's School, Leatherhead (1893-99), and then as a lecturer in mathematics and economics at the new University College, Reading (1900-19). It was not until 1919 that he had a full-time teaching post; he was then elected to the new chair of statistics in the University of London, held at the London School of Economics.
He retired from this chair in 1936 , being made professor emeritus in the University. Afterwards he was called upon to act as director of the Oxford University Institute of Statistics for a war-time period (1940-44).

As a teacher, Bowley was a meticulous expositor and an inspiration to the inquiring mind; but he made few concessions to the weaker students. His influence was greater among postgraduate than undergraduate students, and greater still with mature research workers. Both Lord Stamp in his work on British incomes and property and Lord Beveridge in his Social Insurance Report were greatly indebted to Bowley for technical advice.

$\mathrm{He}$ contributed to the advancement of statistical and economic theory, which he translated into his own mathematical terms. But his more important and lasting work was in the application of statistics to economic and social problems. It can be said that recent developments in such fields as market research arose from his pioneering work, from 1910 onwards, on the use of sampling techniques in social surveys. Equally, practitioners of the art of interpreting current economic movements owe a good deal to his work for the London and Cambridge Economic Service, of which he was editor from the beginning in 1923 until 1945.

His advice was much sought after, both in Great Britain and abroad. He was for many years a member of official committees concerned with the cost of living and related matters. He was active in the affairs of the British Association, holding office 
in Section $F$ from 1899 until 1911. The Royal Statistical Society, of which he was a Council member as early as 1898, awarded him the Guy Medal (Gold) in 1935 and elected him president during 1938-40. The International Statistical Institute called upon him on numerous occasions; he wrote several of the Institute's reports, and he served as treasurer and bureau member during 1929-36 and again from 1947 until 1949. The statistical work of the League of Nations in the early years was furthered by two reports commissioned from him. With Sir Dennis Robertson 'he visited India in 1934 to prepare a scheme for an economic census. He was created C.B.E. in 1937 and made a knight bachelor in 1950 ; he was elected a Fellow of the British Academy in 1922.

Bowley was the author of more than twenty books and pamphlets, in addition to numerous articles, reports and memoranda. Some of them are of continuing value, particularly his "Wages and Income in the United Kingdom since 1860" (published 1937), in which he brings together much of the work on wages he undertook from 1895 onwards. 'Two of his text-books are still used quite widely: "An Elementary Manual of Statistics" (seventh edition, 1951) and "Elements of Statistics" (second impression of sixth edition, 1946).

In the nature of things, Bowley is survived by few of his contemporaries; but he will be missed by all those who know him and so came to appreciate his incisive mind, his liberal outlook and his dry sense of humour.

R. G. D. Allen

\section{Dr. F. A. Henson}

Dr. Fredertck Arthur Henson, lecturer in the Department of Geology, University of Nottingham, died suddenly on January 14. Born at Wolverton,
Bucks, on June 30, 1919, he proceeded to the University of Reading in 1937. During 1940-45 he was on active service, first as a fighter pilot in the Fleet Air Arm and later as staff meteorological officer on the personal staffs of Admiral Somerville and Admiral Mountbatten in the South-East Asia Command. Resuming his studies after distinguished war-time services, he completed his degree course and proceeded to research work in the University of Reading on the geology of the Channel Islands, for which he was awarded the degree of Ph.D. of his University.

In 1947 Dr. Henson was appointed lecturer in the University of Nottingham and developed courses in petrology and economic geology. His work on the Channel Islands continued, and a series of important papers, some of which are still in manuscript, have emerged on the granites and the migration of trace elements associated with granitization in Jersey. During the past three years he stimulated researches on the basalts and associated rocks of Iceland, and with enormous energy and enthusiasm made two expeditions to study these rocks. At the peak of his career it seems so tragic that the results of this important field of research had just reached the stage of publication.

His writings covered a wide variety of topics ; and he was also responsible for the teaching and development of a complete university course of study in photogrammetry. He was an active member of the Board of the Faculty of Pure Science in the University of Nottingham, the University representative on the Outward Bound Trust and a lieutenant-commander in the R.N.V.R. His stimulus and influence on all sections of University life will be a great loss, and his ever-ready help to expeditionary projects will be sadly missed by the undergraduates of the Universities of Nottingham and Reading.

\section{NEWS and VIEWS}

Physics at the Imperial College: Dr. C. C. Butler

Dr. C. C. ButLer has been appointed to the chair in physics tenable at the Imperial College of Science and Technology, London, left vacant when Prof. S. Devons was appointed to the University of Man. chester in 1955. Dr. Butler, who was born in 1922, graduated at the University of Reading in 1942. His first postgraduate work was with T. B. Rymer at Reading on precision measurements in electron diffraction. In 1945 he became assistant lecturer in physics in the University of Manchester and lecturer in 1947. When Prof. P. M. S. Blackett moved to the Imperial College in 1953, Dr. Butler was appointed reader in the University of London, and since 1955 he has been assistant director of the physical laboratories at the Imperial College. During 1946-47 in Manchester, Dr. Butler, in collaboration with Dr. G. D. Rochester (now professor of physics in the Durham Colleges in the University of Durham), discovered the charged and neutral $V$-particles, using a countercontrolled eloud chamber in a magnetic field. In 1956 the Physical Society awarded them jointly the Charles Vernon Boys Prize for this work. In 1951 Dr. Butler moved this apparatus to the Pic-du-Midi laboratory in the Pyrenees and has directed the work of the group running it ever since. Very soon after the work started in the mountains, the negative cascade hyperon was discovered and the neutral $V$-particle transforming into a proton and a meson was first identified.

\section{Ministry of Supply: Chemical Defence Research : Mr. A. E. Childs, C.B.E.}

ON January 16, after thirty-six years continuous service in the field of chemical defence research, Mr. A. E. Childs retired from the headquarters post of director of chemical defence research and development in the Ministry of Supply. He graduated at the University of Cambridge in 1920 and later at the University of London. During the First World War he held appointments as divisional gas officer and general staff officer (3) with the British Expeditionary Force in France. In 1921 he joined the staff of the Chemical Warfare Research Station, Porton, where his resourceful and energetic disposition found ample scope. Later, he held senior posts in the chemical and research divisions of the Establishment. During the Second World War his activities included a mission to chemical warfare establishments in the Commonwealth countries and the United States, and in 1943 he was appointed principal technical adviser to Mr. Davidson Pratt, the controller of research and development in the chemical warfare field. At the end of the War Mr. Childs became leader of the 